\title{
Croton thomasii Riina \& P. E. Berry (Euphorbiaceae), a new species from the Atlantic Forest in the State of Bahia (Brazil) and typification of Croton sapiifolius Müll. Arg.
}

\author{
Ricarda Riina, Inês Cordeiro, André M. Amorim \& Paul E. Berry
}

\begin{abstract}
RIINA, R., I. CORDEIRO, A. M. AMORIM \& P. E. BERRY (2010). Croton thomasii Riina \& P. E. Berry (Euphorbiaceae), a new species from the Atlantic Forest in the State of Bahia (Brazil) and typification of Croton sapiifolius Müll. Arg. Candollea 65: 101-107. In English, English and French abstracts.

Croton thomasii Riina \& P. E. Berry (Euphorbiaceae), a new tree species from the Atlantic forest of southern Bahia, Brazil, is described and illustrated. It is compared with Croton sapiifolius Müll. Arg., previously known only from the type collection, for which a detailed description and a first illustration are given. A lectotype is designated for Croton sapiifolius. Taxonomical affinities of these two species are also briefly discussed using both morphological and molecular data.
\end{abstract}

\section{Key-words}

EUPHORBIACEAE - Croton - Brazil State of Bahia - Atlantic Forest - Taxonomy - Typification

\begin{abstract}
Résumé
RIINA, R., I. CORDEIRO, A. M. AMORIM \& P. E. BERRY (2010). Croton thomasii Riina \& P. E. Berry (Euphorbiaceae), une nouvelle espèce de la Forêt Atlantique de l'Etat de Bahia (Brésil) et typification de Croton sapiifolius Müll. Arg. Candollea 65: 101-107. En anglais, résumés anglais et français.

Croton thomasii Riina \& P. E. Berry (Euphorbiaceae), une nouvelle espèce d'arbre de la Forêt Atlantique du Sud de Bahia, Brésil, est décrite et illustrée. Elle est comparée avec Croton sapiifolius Müll. Arg., une espèce connue seulement par son type, dont une description détaillée et une illustration sont données. Un lectotype est désigné pour Croton sapiifolius. Les affinités taxonomiques de ces deux espèces sont aussi brièvement discutées sur la base de données morphologiques et moléculaires.
\end{abstract}

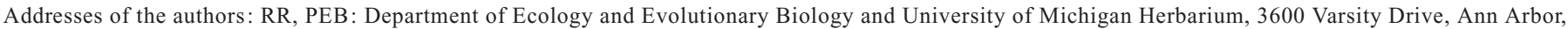
MI 48109-2287, USA.

Email (RR): riina@umich.edu

IC: Instituto de Botânica, Secretaria do Meio Ambiente, Cx. Postal 3005, 01061-970, São Paulo, SP, Brazil.

AMA: Universidade Estadual de Santa Cruz, Departamento de Ciências Biológicas, Km 16 da Rodovia Ilhéus - Itabuna, 45.650-970, Ilhéus, BA, Brazil. 
Croton L. (Euphorbiaceae s.s.) is a genus of over 1220 currently recognized species worldwide (GOVAERTS \& al., 2000; BERRY \& al., 2005) with between 300-350 of them occurring in Brazil, one of the genus' hotspots of diversity (BERRY \& al., 2005; Caruzo, 2005; Caruzo \& Cordeiro, 2007). Here we focus on two arborescent species from the Brazilian state of Bahia, where about 60 species of Croton occur, most of them small shrubs occurring in littoral forests (restingas), dry forests (matas de cipó), and secondary vegetation.

The new species Croton thomasii Riina \& P. E. Berry is described and illustrated below, and the taxonomy and morphology of the poorly known Bahian species $C$. sapiifolius Müll. Arg. (Croton sect. Quadrilobus Müll. Arg.) is updated.

\section{Croton thomasii Riina \& P. E. Berry, spec. nova (Fig. 1)}

Typus: BraziL. Bahia. Municipio Ilhéus: $2 \mathrm{~km}$ NNE of Banco da Vitória (5.7 km west of bridge over the Rio Fundão on road to Itabuna) on road leading to west edge of the Mata da Esperança, disturbed Southern Bahian wet forest with some logged trees and adjacent intact forest, 1446'38"W 3905'28"S, 15.I.1995, W. W. Thomas, J. Jardim, S. Sant'Ana \& J. L. da Paixão 10793 (holo-: CEPEC; iso-: G, MBM, MO, NY, SP).

Arbor 9-18-metralis C. priscus affinis, glandulis petiolorum sessilibus, staminibus 15-16, sepalis foemineis maioribus, fructibus non muricatis differt.

Monoecious tree 9-18 m high, ca. 11-20 cm DBH; apex of young branches and leaves covered with a sparse to dense whitish indumentum of stellate-rosulate trichomes; upper surface of foliage dark shiny green, lower surface pale-green; latex reddish. Stipules linear, caducous (only present on apical and young nodes), 5-7 $\mathrm{mm}$ long. Leaves alternate, ovate to elliptic, 6-20 $\times 4-14 \mathrm{~cm}$, apex acute to obtuse, base rounded to broadly cuneate; margin loosely dentate with a minute discoid gland usually present at end the of teeth or/and at sinuses; venation brochidodromous, 4-6 lateral veins per side of the midrib, veins raised on the abaxial surface; adaxial and abaxial leaf indumentum very sparse, mostly restricted to the veins; trichomes stellate-rosulate; petiolar glands 2, acropetiolar, sessile, attached to the petiole on the abaxial surface, patelliform, 0.8-1 mm diam.; petioles 3-6 cm long, with stellate-rosulate trichomes. Inflorescences terminal, $12-20 \mathrm{~cm}$ long; basal cymules apparently bisexual, rachis with stellate-rosulate indumentum. Staminate flowers numerous and densely distributed along the inflorescence; pedicels 1-3 mm long; sepals 5, valvate, ovate, acute, $1.5-2.5 \mathrm{~mm} \times 1-1.3 \mathrm{~mm}$, adaxial surface mostly glabrous, abaxial surface and margins with a more or less dense indumentum of stellate-rosulate trichomes; petals 5, linear-oblong, $1.5-2.4 \mathrm{~mm} \times 0.6-0.8 \mathrm{~mm}$, adaxially grabrous or with sparse stellate-rosulate trichomes, abaxial surface and margins with a \pm dense indumentum of stellate trichomes; receptacle densely pilose; stamens $15-16$; filaments $2-3 \mathrm{~mm}$ long; anthers $0.8-1 \mathrm{~mm} \times 0.5-0.6 \mathrm{~mm}$. Pistillate flowers at the base of the rachis, fruiting pedicels $2-2.5 \mathrm{~cm}$ long; sepals (in fruit) $8-15 \times 5-10 \mathrm{~mm}$, oblong-ovate, apex rounded, abaxial surface sparsely covered with stellate-rosulate trichomes; no petals; ovary and fruit covered with whitish stellate-rosulate trichomes; styles quadrifid. Capsules globose, trilocular, 1-1.5 $\times$ 0.9-1.4 cm, covered with sparse stellate-rosulate trichomes; seeds 3 , broadly oblong, $1 \times 1.1 \mathrm{~cm}$, surface smooth, dark brown, caruncle transversally elliptic.

Distribution and habitat. - Apparently endemic to southern Bahia, Brazil, in wet forests at elevations of 100150 meters. The species occurs along forest trails and gaps, where many seedlings and saplings are usually found.

Etymology. - The new species is dedicated to Wm. Wayt Thomas, curator at the New York Botanical Garden (NY), who has contributed extensively to our knowledge of the Brazilian coastal forests and continues to work actively with Brazilian botanists on the vegetation and flora of Bahia state in southeastern Brazil.

Common names. - Local common names of the species are "Taipoca" (Rylands \& Hages 101) and "Embira" (Rylands \& Hages 196).

Taxonomical notes. - Most of the specimens of C. thomasii were previously determined as C. piptocalyx Müll. Arg. The foliage of $C$. thomasii is similar in its sparse pubescence to that of C. piptocalyx, C. priscus Croizat, and C. sapiifolius, but the new species differs from the three others in several morphological features (Table 1). Phylogenetic studies using both nuclear ITS and chloroplast trnL-F sequences place $C$. thomasii as the sister species of C. priscus and C. eichleri Müll. Arg. (RIINA \& al., 2009). In RiINA \& al. (2009), C. thomasii is included as a new species of Croton. Morphological similarities between $C$. priscus and $C$. thomasii support this phylogenetic placement (Table 1).

Croton sapiifolius and C. thomasii occur sympatrically in some localities, and both are endemic to the southern Bahia wet forests. The two species share some similarities in their foliage and other vegetative features, and specimens of both have been previously determined as C. piptocalyx.

Additional specimens examined. - BrazIL. Bahia: Município de Una: Reserva Biológica de Una (IBAMA), Entrada no km 46 da Rod. BA 001 Ilhéus-Una, trilha paralela a área de plantação de cacao cabruca, 23.V.1999, J. G. Jardim, R. E. Raboy, S. C. Sant'Ana \& G. Gomes Mota 2142 (CEPEC); Reserva Biológica de Una, trilha de acesso a sede da Reserva, 21.I.2006, J. L. da Paixão, A. M. Amorim, W. Thomas \& R. Riina 653, 654 (CEPEC); W of Olivença-Una road on road to Vila Brasil, just $\mathrm{N}$ of Rio Acuipe bridge, then at $19 \mathrm{~km}$ on road to Faz. 2 de Julho, $18^{\circ} 08^{\prime}$ S $39^{\circ} 14^{\prime}$ W, 11.II.1994, J. Kallunki, J. R. Pirani, I. Cordeiro \& P. L. R. de Morales 502 (SPF, NY); 


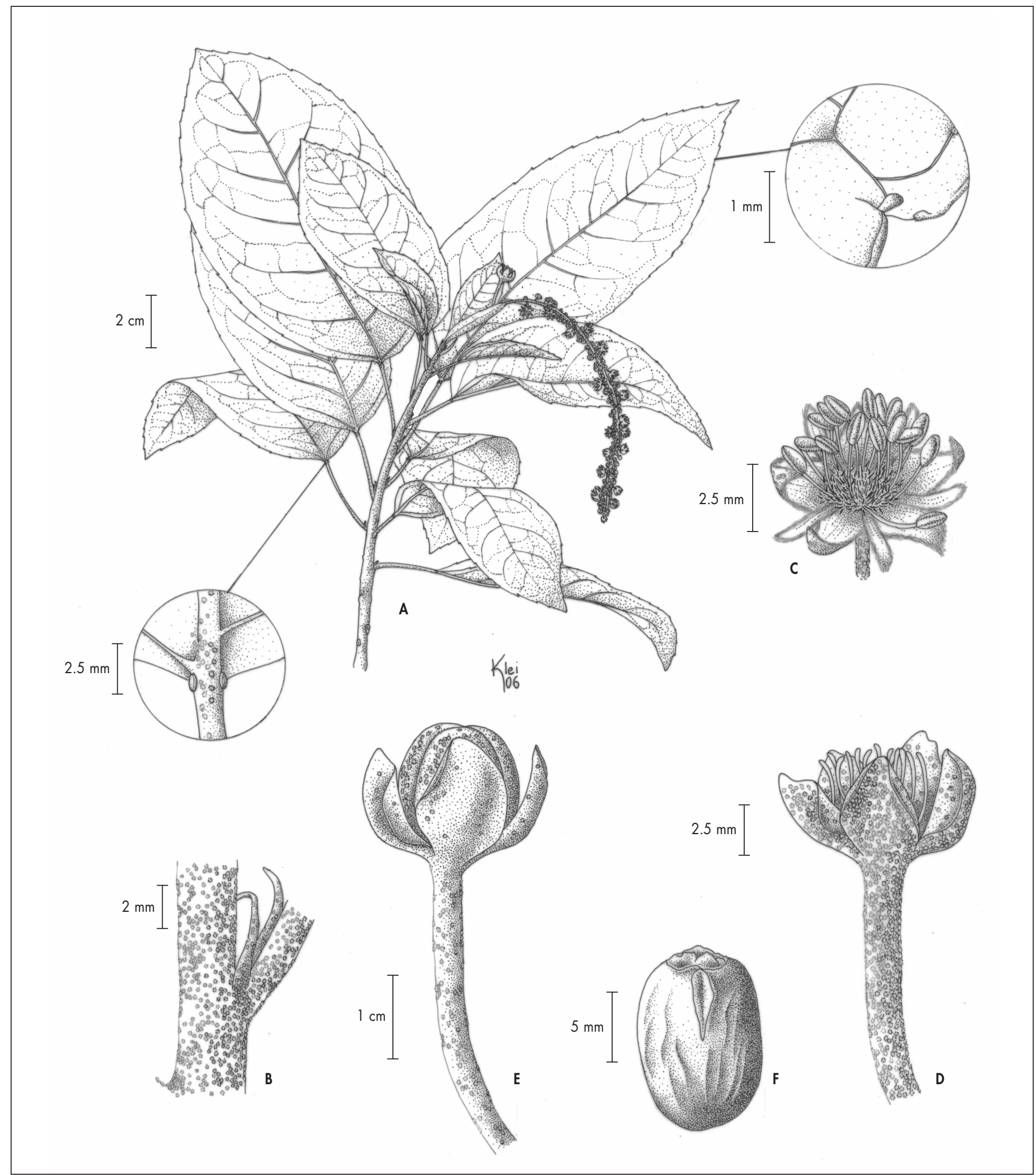

Fig. 1. - Croton thomasii Riina \& P. E. Berry. A. Flowering branch with details of petiolar and marginal glands; B. Stipules; C. Staminate flower; D. Pistillate flower; E. Fruit; F. Ventral view of seed.

[A, B, C: Thomas 10793, CEPEC; D, E, F: Kallunki 502, SPF] [Drawings: Klei Rodrigo Souza] 
Estação Experimental Lemos Maia, CEPLAC, Floresta ao lado W da estação, 12.XI.1980, A. Rylands \& J. L. Hage 101 (CEPEC); Estação Experimental Lemos Maia, CEPLAC, Floresta ao lado W da estação, 19.XI.1980, A. Rylands \& J. L. Hage 196 (NY, CEPEC).

Croton sapiifolius Müll. Arg. in Linnaea 34: 137. 1865 (Fig. 2).

Lectotypus (here designated): BRAZIL: "in Brasilia", Sellow 557 (G-DC!; iso-: A!, B [destroyed, photo F-neg. 5159]!, G!, P).

Shrub to tree 2-14 m high, 2-15 cm DAP, apparently dioecious; young branches either glabrous or covered with a whitish, sparse to dense indumentum of stellate and stellatelepidote trichomes; latex not observed. Stipules minute, triangular, $1 \mathrm{~mm}$ long, the apex with one gland, the base with two glands. Leaves alternate, coriaceous, oblong or elliptic, 13-32 $\times 7-16 \mathrm{~cm}$, apex acute to obtuse, shortly acuminate, base rounded to broadly cuneate; margin entire to sinuous or dentate with discoid, sessile glands in the sinuses at \pm regular intervals and ovoid glands on the teeth; venation brochidodromous, 4-6 lateral veins per side of the midrib, veins raised on both surfaces; adaxial and abaxial leaf indumentum very sparse, mostly restricted to the veins; trichomes stellate-lepidote; petiolar glands 2(-4), acropetiolar to epipetiolar, sessile, attached to the petiole on the adaxial surface, globose, $0.8-1 \mathrm{~mm}$ diam., petioles 2-13 cm long, with indumentum of stellate-lepidote trichomes. Staminate inflorescences thyrsoid, axillary, slender, 5-20 cm long, with a whorl of 4-5 bracts at the base, bracts 3$5 \times 1-2 \mathrm{~mm}$; rachis angular, with stellate-lepidote trichomes. Pistillate inflorescences appearing cymose, terminal, $5-15 \mathrm{~cm}$ long, usually with a whorl of 4-5 bracts at the base, bracts 3$5 \times 1-2 \mathrm{~mm}$, rachis angular, with stellate or stellate-lepidote porrect trichomes. Staminate flowers 3-6, distributed along the inflorescence on the upper half of the rachis; pedicels $1-5 \mathrm{~mm}$ long; sepals 4, valvate, ovate, acute, $1-2.5 \mathrm{~mm} \times 1-1.5 \mathrm{~mm}$, adaxial surface glabrous, abaxial surface with stellate-lepidote trichomes; petals 4, oblong, $1-2.5 \mathrm{~mm} \times 1-1.5 \mathrm{~mm}$, adaxial surface and edges lanose, abaxial surface glabrous; receptacle densely pilose; stamens $10-15$; filaments $2-3 \mathrm{~mm}$ long; anthers $1.1 \mathrm{~mm} \times 0.6 \mathrm{~mm}$. Pistillate flowers $3-5$, spaced along the rachis, or sometimes concentrated on a short cyme, pedicels 4-5 mm long; sepals 4, 2.5-5 × 2-2.5 mm, triangular, apex acute, abaxial surface sparsely covered with stellate-lepidote, sometimes porrect, trichomes; petals absent; ovary and fruit densely covered with golden-yellow, stellate and stellatelepidote, porrect, trichomes; styles 3 , bifid, covered by sparse stellate and stellate-lepidote trichomes. Capsules obovate, 2(-3)-locular, $2.5 \times 1.4 \mathrm{~cm}$, covered with dark golden yellow, stellate and stellate-lepidote porrect trichomes; seeds 2(-3), broadly obovoid, $1.8 \times 1.3 \mathrm{~cm}$, surface smooth, dark brown, caruncle \pm reniform or depressed ovate.
Distribution and habitat. - Apparently endemic to southern Bahia, in moist forests at 100-200 meters elevation.

Additional specimens examined. - BrazIL. Bahia: Município Jussari : Reserva Particular do Patrimônio Nacional Serra do Teimoso, $15^{\circ} 09^{\prime}$ S $39^{\circ} 31^{\prime} \mathrm{W}$, 26.I.2006, J. L. da Paixão, M. M. Lopes, R. Riina \& S. C. Sant Ana 667 (CEPEC, NY, SP). Município de Uruçuca: Estrada que liga Uruçuca ao Distrito de Serra Grande, coletas efetuadas $30.7 \mathrm{~km}$ a partir da sede do município, Mata Higrófila, 2.I.1992, A. M. Amorim, S. C. Sant'Ana, I.C. Nascimento \& J. G. Jardim 627 (CEPEC, NY, SP); Distrito de Serra Grande, $7.3 \mathrm{~km}$ na estrada Serra Grande/Itacaré, Fazenda Lagoa do conjunto Fazenda Santa Cruz; $14^{\circ} 25^{\prime}$ S 3901'W, 1-12.VII.1991, A. M. Carvalho, W. W. Thomas \& T. S. dos Santos 3365, 3399 (CEPEC, NY, SP), A. M. Carvalho, W. W. Thomas \& T. S. dos Santos 3400 (CEPEC, DAV, MBM, MO, NY, SP); $7.5 \mathrm{~km} \mathrm{~N}$ of Serra Grande on road to Itacaré, Fazenda Lagoa do Conjunto Fazenda Santa Cruz, $14^{\circ} 25^{\prime}$ 'S, $39^{\circ} 01^{\prime} \mathrm{W}, 1-12$.VII.1991, $W$. W. Thomas, A. M. de Carvalho \& T. S. dos Santos 7167, 7357, 8687 (CEPEC, NY); nova estrada que liga Uruçuca à Serra Grande, a 28-30 km de Uruçuca, 1.V.1979, S. Mori 11765 (CEPEC); nova estrada que liga Uruçuca à Serra Grande, a 28-30 km de Uruçuca, 16.VII.1978, S. Mori, F. Benton \& I. White 10247 (CEPEC, DAV). Município de Una: Estrada de Una para Santa Luzia, ca. $1 \mathrm{~km}$ da Vila de São João (ca. $20 \mathrm{~km}$ de Una), ramal à esquerda, $15^{\circ} 23^{\prime} \mathrm{S} 39^{\circ} 12^{\prime} \mathrm{W}, 4$.XII. 2002, P. Fiaschi, J. A. Kallunki, S. C. Sant'Ana, J. L. da Paixão 1241 (CEPEC, NY); Reserva Biológica do Mico-Leão (IBAMA), entrada no km 46 da Rod. BA 001 Ilhéus-Una, 1509'S 3905'W, 5.VII.1996, S. C. Sant'Ana, J. G. Jardim, H. S. Brito \& J. A. L. dos Santos 601 (CEPEC, NY, SP).

Taxonomical notes. - The original description of the monotypic Croton sect. Quadrilobus indicates that the ovary of C. sapiifolius is 3-locular. However all the specimens we have examined have 2-locular ovaries with the exception of one, Sant'Ana 601, which has three locules. Unfortunately, the fruits from the type specimens were probably lost (or are in Lenorman herbarium (P) collection which we have not seen), since Müller described the capsule in the species protologue. The presence of three bifid styles on the specimens with bilocular ovaries suggests that the abortion of one of the ovules is producing 2-locular capsules in some individuals.

There is no mention whether C. sapiifolius is dioecious or monoecious in the protologue. We suspect that it is dioecious given the differences found in the inflorescences from the specimens examined. None of the specimens examined have bisexual inflorescences, and the fact that the inflorescences bearing pistillate flowers or fruits are determinate, and the staminate ones are indeterminate (like most Croton species) could be an indication that $C$. sapiifolius is dioecious. However, additional field observations are needed to corroborate this hypothesis. 


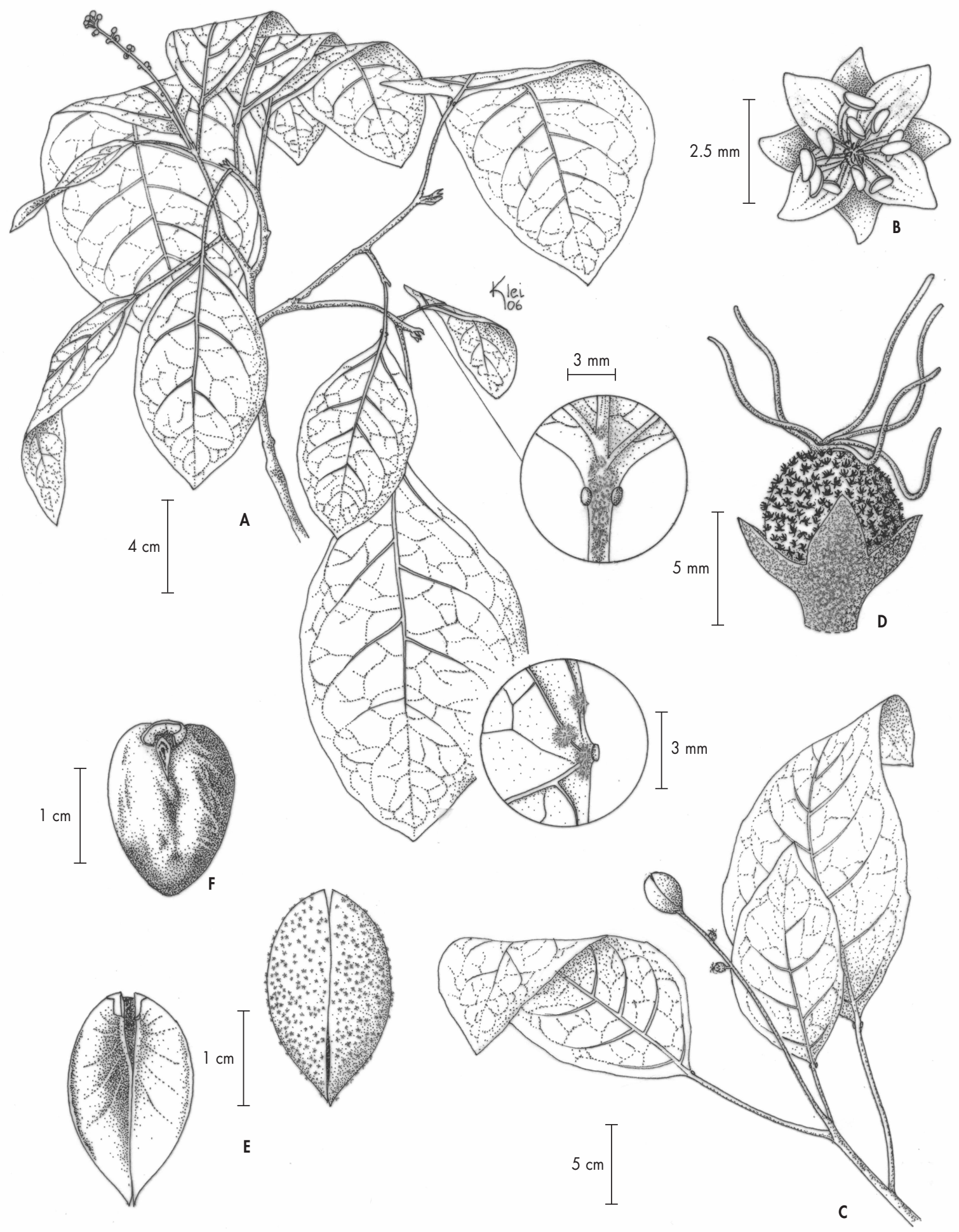

Fig. 2. - Croton sapiifolius Müll. Arg. A. Branch with a young staminate inflorescence and details of petiolar and marginal glands; B. Staminate flower; C. Fruiting branch; D. Pistillate flower; E. Ventral and dorsal views of one of the capsular cocci from a 2-locular ovary; F. Ventral view of seed.

[A, B: Mori \& al. 10247, CEPEC; C, D: Mori 11765, CEPEC; E, F: Thomas \& al. 7357, CEPEC] [Drawings: Klei Rodrigo Souza] 
The cymose pistillate inflorescence in $C$. sapiifolius is very unusual in Croton. Most species in the genus have narrow thyrsoid indeterminate inflorescences bearing determinate thyrses (or cymules) with their axis so reduced that they appear lacking. One possibility is that the pistillate inflorescence of C. sapiifolius is reduced to a single unisexual thyrse with an unusual long axis. Additional field observations and additional herbarium material with several stages of inflorescence development will be needed to clarify this issue.

Specimens of $C$. sapiifolius were previously determined as $C$. aff. piptocalyx. Despite its affinity with C. piptocalyx, it can be easily distinguished from it by the carpel number (two or three in C. sapiifolius and three in C. piptocalyx), staminate flowers merosity (tetramerous vs. pentamerous), and persistency of calyx in fruit (persistent vs. deciduous). Additional differences between the two species are indicated in Table 1. WeBster (1993) referred to C. sapiifolius as an imperfectly known species, and he also mentioned that sect. Quadrilobus was very similar to the Old World Croton sect. Tiglium (Klotzsch) Baill., with the exception of the tetramerous perianth of sect. Quadrilobus. Our morphological studies and evidence from DNA sequence data show that members of Croton sect. Tiglium, along with all Old World Croton species, are not most closely related to C. sapiifolius (RIINA \& al., 2009). All the Old World Croton species sequenced so far form a monophyletic group nested within the New World Croton (BERRY \& al., 2005; vAN EE \& al., 2008; RiINA \& al., 2009). Results from the analyses of nuclear ITS and chloroplast trnL-F sequence data show that C. sapiifolius belongs with other South American species: the Sampatik clade (RIINA \& al., 2009), the South American Grade (VAN EE \& al., 2008). This latter includes C. piptocalyx, C. sampatik Müll. Arg., C. ater Croizat, and possibly $C$. trombetensis Secco, P. E. Berry \& N. A. Rosa (Rirna \& al., 2009).

\section{Acknowledgments}

We wish to thank Klei Rodrigo Souza for the line drawings and Wayt Thomas, José Lima da Paixão, Sérgio Sant'Ana, and Márdel Mendes Lopes for their collaboration and assistance in the field. We are also grateful to the herbaria A, B, CEPEC, DAV, F, G, MBM, MO, NY, SP, and SPF for providing access to their collections, and to Nicolas Fumeaux $(G)$ for his invaluable help with nomenclatural issues. Financial support for a field trip to Brazil was provided to the senior author by The Lawrence Memorial Award from the Hunt Institute for Botanical Documentation, the William R. Anderson Graduate Student Research Grant Fund from the American Society of Plant Taxonomists (ASPT), and the U.S. National Science Foundation (award \# DEB-0212481 to P. Berry).

Table 1. - A selection of morphological differences and similarities between Croton thomasii Riina \& P. E. Berry, C. piptocalyx Müll. Arg., C. priscus Croizat, and C. sapiifolius Müll. Arg.

\begin{tabular}{|c|c|c|c|c|}
\hline Character & C. thomasii & C. priscus & C. piptocalyx & C. sapiifolius \\
\hline Predominant trichome types & Stellate-rosulate & Stellate-rosulate & Stellate-lepidote, lepidote & Stellate-lepidote, lepidote \\
\hline Staminate flower & 5-merous & 5-merous & 5-merous & 4-merous \\
\hline Stamens & $15-16$ & 18 & $15-20$ & 15 \\
\hline Ovary & 3-locular & 3-locular & 3-locular & 2-3-locular \\
\hline Capsule shape & Slightly sulcate & Not sulcate & Deeply sulcate & Not sulcate \\
\hline Fruit surface & Not muricate & Strongly muricate & Not muricate & Not muricate \\
\hline Sexual system & Monoecious & Monoecious & Monoecious & Dioecious \\
\hline
\end{tabular}




\section{References}

Berry, P. E., A. L. HipP, K. J. Wurdack, B. VAn Ee \& R. RiInA (2005). Molecular phylogenetics of the giant genus Croton and tribe Crotoneae (Euphorbiaceae sensu stricto) using ITS and trnLtrnF DNA sequence data. Amer. J. Bot. 92: 1520-1534.

CARuzo, M. B. (2005). Estudo taxonômico e biogeográfico do gênero Croton L. (Euphorbiaceae) no estado de São Paulo, Brasil. Masters thesis. Universidade de São Paulo.

Caruzo, M. B. \& I. Cordeiro (2007). Sinopse da tribo Crotoneae Dumort. (Euphorbiaceae s.s.) no Estado de São Paulo, Brasil. Hoehnea 34: 571-585.

Govaerts, R., D. G. Frodin \& A. Radcliffe-Smith (2000). World checklist and bibliography of Euphorbiaceae. Royal Botanic Gardens, Kew.

RiINA, R., P. E. BERRY \& B. VAN EE (2009). Molecular phylogenetics of the dragon's blood Croton section Cyclostigma (Euphorbiaceae): A polyphyletic assemblage unraveled. Syst. Bot. 34: 360-374

Van Ee, B. W., P. E. Berry, R. Riina \& J. E. Gutierrez Amaro (2008). Molecular Phylogenetics and Biogeography of the Caribbean-centered Croton subgenus Moacroton (Euphorbiaceae s.s.). Bot. Rev. (Lancaster) 74: 132-165.

Webster, G. L. 1993. A provisional synopsis of the sections of the genus Croton (Euphorbiaceae). Taxon 42: 793-823. 